\title{
ANALISIS FAKTOR-FAKTOR YANG MEMPENGARUHI MINAT MENGGUNAKAN FINTECH LENDING
}

\author{
Samuel Martono* \\ Universitas Kristen Satya Wacana, Indonesia
}

\begin{abstract}
This study aims to examine the determinants of the developed Technology Acceptance Model (TAM) framework. The author used stratified random sampling, and data collection used a survey method. The analysis technique used is multiple regression analysis and path analysis using the IBM SPSS 25 software. The results show that perceived ease of use and perceived risk do not influence attitude towards fintech lending. In contrast, perceived usefulness, relative advantage, and perceived cost influence it, and attitude influences intention to use fintech lending behavior. Moreover, the attitude has a partial mediation role only in the relationship between perceived usefulness and relative advantage to fintech lending using intention. These results support the original model of TAM that states perceived ease of use has a nonsignificant effect on attitude towards using behavior. It suggested that financial technology services foster users to use fintech lending through various ways to tell it is easy enough to use and able to protect users' secure data and information. This study also contributes to giving more empirical evidence for other variables to modify and develop the Technology Acceptance Model.
\end{abstract}

JEL : G23, G41, G51.

Keywords : Technology Acceptance Model, financial technology, lending.

\begin{abstract}
ABSTRAK
Penelitian ini bertujuan untuk menguji faktor-faktor pada kerangka kerja yang merupakan pengembangan dari Technology Acceptance Model (TAM). Peneliti menggunakan metode stratified random sampling dan pengumpulan data dilakukan dengan menggunakan metode survey. Teknik analisis yang digunakan adalah uji regresi berganda dan uji jalur dengan bantuan perangkat lunak IBM SPSS 25. Hasil penelitian menunjukkan bahwa perceived ease of use dan perceived risk tidak memberikan pengaruh pada sikap terhadap fintech lending. Sebaliknya, perceived usefulness, relative advantage dan perceived cost justru memberikan pengaruh, serta sikap memberikan pengaruh terhadap minat untuk menggunakan fintech lending. Lebih lanjut, sikap memilki mediasi parsial hanya pada hubungan antara perceived usefulness dan relative advantage terhadap minat untuk menggunakan fintech lending. Hasil penelitian ini mendukung model awal TAM yang menyatakan bahwa perceived ease of use memberikan pengaruh yang tidak signifikan terhadap sikap untuk menggunakan. Disarankan bagi penyedia jasa keuangan berbasis teknologi untuk mendorong pengguna fintech lending melalui berbagai langkah untuk menyampaikan kemudahan penggunaan dan fintech mampu melindungi data dan informasi pengguna yang bersifat rahasia. Penelitian ini juga berkontribusi untuk memberikan bukti empiris pada berbagai variabel yang digunakan untuk memodifikasi dan mengembangkan Technology Acceptance Model.
\end{abstract}

Kata Kunci : Technology Acceptance Model, teknologi finansial, pinjaman.

\section{PENDAHULUAN}

Financial technology (fintech) merupakan layanan keuangan inovatif yang berkembang bersamaan dengan pesatnya kemajuan teknologi (Huei, Cheng, Seong, Khin \& Bin, 2018) yang telah berkembang dengan pesat dalam berbagai bentuk dan platform, mulai dari bentuk dompet virtual, pembayaran mobile (Kim, Park, Choi \& Yeon, 2015), media untuk mendapatkan saran perencanaan keuangan, melakukan investasi dan memperoleh pinjaman yang bersumber dari

\footnotetext{
${ }^{*}$ Email : samuel.martono@uksw.edu

Received : 23-03-2021, Accepted : 22-12-2021, Published : 28-12-2021

P-ISSN : 2087-9954, E-ISSN : 2550-0066. DOI : http://dx.doi.org/10.26418/jebik.v10i3.45827
} 
beberapa pemilik modal (crowdfunding) (Huei et al., 2018), sehingga telah menjadi salah satu industri yang paling menjanjikan (Chishti \& Barberis, 2016) karena berfokus pada penerapan teknologi baru (Chuang, Liu \& Kao, 2016). Lebih lanjut, Financial Stability Board (2017) membagi fintech ke dalam lima kategori utama, yaitu i) payment, clearing \& settlement, ii) deposit, lending \& capital raising, iii) insurance, iv) investment management, dan v) market support yang bertujuan agar fintech mampu mencakup hampir semua jenis layanan sama seperti yang disediakan oleh lembaga keuangan tradisional (Bofondi \& Gobbi, 2017). Digital online payments telah mendominasi transaksi fintech dengan nilai 622 miliar dollar yang mendekati separuh nilai pembayaran konvensional (Google, Temasek \& Bain, 2019), yang diprediksi akan meningkat hingga delapan kali lipat pada tahun 2025, sehingga pemanfaatan fintech untuk memenuhi kebutuhan bertransaksi akan semakin meningkat. Di Indonesia, meskipun nilai transaksi fintech telah mencapai angka 15 miliar US\$ didominasi oleh transaksi online payments point of sales payment (Daily Social Research, 2019), transaksi peminjaman uang (lending) dinilai telah menjadi sektor yang bertumbuh sangat cepat. Hal ini terlihat dari adanya kenaikan sebesar 36,74\% pada outstanding loan, kenaikan akumulasi penyaluran pinjaman sebesar 134,91\% dengan kenaikan jumlah pinjaman baru sebesar 30,76\%, dan kenaikan rekening peminjam sebesar 132,82\% dengan peningkatan akumulasi transaksi oleh peminjam sebesar 272,57\% (OJK, 2020). Pertumbuhan yang pesat tersebut dapat disebabkan oleh kemampuan fintech lending dalam mengatasi rendahnya inklusi keuangan masyarakat Indonesia (Amalia, 2016) dan juga memiliki kesempatan yang besar untuk menjadi metode alternatif untuk memenuhi kebutuhan pendanaan nasional (Rosavina, Rahadi, Kitri, Nuraeni \& Mayangsari, 2019; Kurniawan, 2019), yang dapat diambil dengan cepat karena fintech lending mampu memberikan layanan pinjaman yang lebih fleksibel (Wei, 2016) dan dapat menyalurkan dana dengan tingkat bunga yang relatif rendah secara lebih efektif dan transparan sehingga mampu melayani peminjam yang layak (Agarwal \& Chua, 2020) melalui penyediaan pinjaman tanpa agunan (Kurniawan, Wardani \& Widhayati, 2019).

Sebagai entitas yang berkembang pesat di bidang keuangan karena telah mampu menjangkau lebih banyak pengguna, dapat dikatakan fintech lending telah diterima oleh sebagian besar masyarakat Indonesia. Oleh karena itu, perlu dilakukan pengukuran mengenai faktor-faktor apa yang membuat fintech lending dapat diterima oleh masyarakat luas. Salah satu model yang dapat mengukur faktor-faktor tersebut adalah Technology Acceptance Model (TAM) yang dinilai tepat untuk digunakan karena mampu memberikan penjelasan yang kuat namun sederhana mengenai penerimaan suatu teknologi dan perilaku penggunanya (Davis, Bagozzi \& Warshaw, 1989). Model TAM menyatakan bahwa minat untuk menggunakan suatu teknologi dipengaruhi oleh keyakinan seseorang terhadap kemampuan dirinya untuk menggunakan teknologi dan penilaian subjektif terhadap manfaat yang dapat diperoleh dari penggunaan teknologi tersebut (Morgan-Thomas \& Veloutsou, 2013). TAM telah digunakan secara luas di beberapa penelitian terdahulu, baik dalam pengukuran tingkat penerimaan fintech secara keseluruhan (Chuang et al., 2016; Suyanto \& Kurniawan, 2019; Darmansyah, Fianto, Hendratmi \& Aziz, 2020), fintech payment (Sijabat, Hutajulu \& Sihombing, 2019; Vuković, Pivac \& Kundid, 2019; Santoso \& Erwin, 2020) dan juga pada fintech lending (Kurniawan, 2019; Kurniawan et al., 2019; Yuniarti \& Ekowati, 2019). Namun demikian, penelitian terdahulu yang menggunakan TAM untuk difokuskan pada fintech lending merupakan penelitian yang paling banyak melakukan modifikasi model dan masih memberikan hasil yang berbeda-beda. Kurniawan (2019) menyatakan bahwa variabel kepercayaan (trust) berpengaruh positif terhadap minat untuk menggunakan fintech lending sedangkan Kurniawan et al. (2019) dan Yuniarti \& Ekowati (2019) menyatakan hasil yang 
berkebalikan. Lebih lanjut, variabel perceived risk dinyatakan memberikan pengaruh negatif terhadap minat untuk menggunakan fintech lending (Yuniarti \& Ekowati, 2019) namun di sisi lain dinyatakan memberikan pengaruh positif untuk menggunakan fintech lending (Kurniawan, 2019), sehingga perlu untuk dilakukan penelitian lebih lanjut untuk memperkaya bukti empirik mengenai model TAM yang digunakan sebagai model dasar pada penelitian-penelitian terdahulu. Terdapat 149 variabel baru yang dapat diintegrasikan dengan model awal TAM (Pantano \& Di Pietro, 2012), namun penelitian ini akan menggunakan kerangka kerja Huei et al. (2018) yang mengembangkan model TAM dengan menambahkan faktor relative advantage, perceived risk dan perceived cost untuk dinilai pengaruhnya masing-masing terhadap sikap pengguna terhadap produk fintech yang kemudian akan mempengaruhi minat untuk menggunakan produk fintech.

Relative advantage merupakan suatu tingkat di mana inovasi yang dimiliki oleh suatu sistem mampu melebihi ekspektasi pengguna sehingga akan dapat memperbesar tingkat kemungkinan untuk diadopsi dan digunakan (Lu, Yang, Chau \& Cao, 2011; Krishanan, Kin \& Teng, 2015) dan secara khusus berkaitan erat dengan niat pengguna dalam menggunakan layanan mobile payment ( $\mathrm{Lu}$ et al., 2011), namun demikian belum ada penelitian yang membuktikan bahwa relative advantage juga mempengaruhi minat untuk menggunakan fintech lending. Perceived risk merupakan tingkat ketidakpastian yang akan dialami pengguna dalam penggunaan sebuah teknologi (risiko keamanan dan risiko penyalahgunaan data dan informasi pribadi) (Bertea, 2011; Amaro \& Duarte, 2015; Cham, Lim, Cheng \& Lee, 2016) yang dapat menjadi faktor penting dalam penggunaannya (Kalinić, Liebana-Cabanillas, Munoz-Leiva \& Marinkovic, 2019) karena akan berpotensi merugikan pengguna. Perceived risk memberikan dampak yang besar terhadap minat pengguna dalam penggunaan sistem pembayaran (Martins, Oliveira \& Popovic, 2014), sehingga dapat diduga bahwa perceived risk juga memberikan dampak yang sama terhadap minat penggunaan fintech lending. Perceived cost dinyatakan dapat mempengaruhi minat penggunaan suatu teknologi karena setiap pengguna memiliki tingkat persepsi yang berbeda terhadap biaya yang akan timbul dalam menggunakan suatu sistem (Kleijnen, Wetzels \& de Ruyter, 2004) sehingga berdampak pada minat penggunaannya. Perceived cost dapat mempengaruhi minat penggunaan layanan tambahan mobile banking (Wu \& Wang, 2005) dan mobile commerce (Kuo \& Yen, 2009), namun masih belum dapat dibuktikan apakah memberikan pengaruh yang sama terhadap penggunaan fintech lending. Berdasarkan paparan tersebut, maka penelitian ini bertujuan untuk memberikan bukti empiris penggunaan kerangka kerja tersebut khususnya untuk mengukur tingkat penerimaan fintech lending dan minat masyarakat untuk menggunakan produk fintech lending. Selain itu, hasil dari penggunaan kerangka kerja tersebut pada penelitian ini juga diharapkan dapat dipakai untuk pengembangan fintech lending di Indonesia.

\section{KAJIAN LITERATUR}

\subsection{Minat untuk Menggunakan Fintech Lending}

Minat didefinisikan sebagai tingkat seberapa kuat kecenderungan seseorang untuk melakukan perilaku tertentu (Davis et al., 1989). Minat juga dapat diartikan sebagai suatu ketertarikan pada suatu hal atau aktivitas tanpa adanya paksaan dari pihak luar (Yuniarti \& Ekowati, 2019). Lebih lanjut, minat untuk melakukan suatu hal dapat dipengaruhi banyak faktor, antara lain kemudahan dalam melakukan hal tersebut, manfaat yang diperoleh dari melakukan hal tersebut, keunggulan yang relatif lebih tinggi dibanding alternatif lain yang sejenis, risiko yang mungkin timbul, biaya yang akan dikeluarkan untuk memperoleh manfaat dari hal tersebut dan 
juga sikap terhadap hal yang akan dilakukan tersebut. Hal yang sama juga berlaku pada minat untuk menggunakan fintech lending, yang dipengaruhi oleh kemudahan dalam penggunaan aplikasi fintech lending dan kebermanfaatan dari penggunaannya (Davis et al., 1989), keunggulan yang relatif lebih tinggi dibanding jenis layanan dan bentuk layanan yang lain serta risiko yang mungkin timbul dari penggunaan fintech lending (Lu et al., 2011), biaya yang harus dikeluarkan untuk memperoleh manfaat dari penggunaan fintech lending (Luarn \& Lin, 2005) serta sikap terhadap penggunaan aplikasi fintech lending tersebut (Davis et al., 1989).

\subsection{Technology Acceptance Model (TAM)}

Technology Acceptance Model (TAM) merupakan model yang menjelaskan dampak dari variabel-variabel eksternal terhadap kepercayaan internal pribadi dan sikap individu yang kemudian akan berdampak pada minat individu untuk menggunakan suatu teknologi (Davis, 1986). Model tersebut kemudian dikembangkan oleh Davis et al. (1989) menjadi sebuah model yang secara lebih efisien mampu menjelaskan dan memprediksi minat pengguna suatu teknologi. Model yang merupakan hasil modifikasi dari model Theory of Reasoned Action (TRA) (Fishbein \& Ajzen, 1975) ini menjelaskan bahwa persepsi kemudahan penggunaan (perceived ease of use), persepsi kegunaan (perceived usefulness) dan sikap (attitude) akan mempengaruhi minat untuk menggunakan yang kemudian akan berdampak pada penggunaan aktual sebuah teknologi. Pada beberapa penelitian terdahulu, meskipun TAM telah digunakan sebagai model dasar untuk dikembangkan (Muk \& Chung, 2015; Tarhini, Hassouna, Abbasi \& Orozco, 2015) namun variabel perceived ease of use dan perceived usefulness disarankan untuk tetap digunakan karena selain mampu untuk memprediksi minat pengguna juga dapat memperkirakan perilaku pengguna dalam menerima suatu teknologi (Svendsen, Johnsen, Almas-Sorensen \& Vitterso, 2013).

Perceived ease of use didefinisikan sebagai tingkat di mana seorang pengguna akan memiliki penilaian bahwa tidak diperlukan usaha yang sangat besar untuk mempelajari dan menggunakan suatu teknologi (Davis et al., 1989). Selain itu, perceived ease of use juga ditentukan oleh berapa banyak waktu yang dibutuhkan untuk menggunakan suatu teknologi dalam mencapai tujuan penggunaan tertentu (Chuang et al., 2016). Semakin kecil usaha dan semakin singkat waktu yang dibutuhkan untuk menggunakan suatu teknologi dalam mencapai tujuan penggunaan tertentu maka akan menaikkan tingkat perceived ease of use, sehingga berpengaruh positif terhadap sikap pengguna akan suatu teknologi. Lebih lanjut, perceived usefulness didefinisikan sebagai tingkat di mana seorang pengguna akan memiliki anggapan bahwa teknologi yang digunakan mampu memberi dampak langsung bagi kinerjanya (Davis et al., 1989) yang dapat dilihat melalui peningkatan aktivitas operasional dan efektivitas kinerja pengguna dapat meningkatkan minat pengguna untuk menggunakannya (Al-Fahim, Jusoh \& Abideen, 2016). Semakin besar dampak positif yang dirasakan oleh pengguna dari penggunaan suatu teknologi maka akan meningkatkan perceived usefulness, sehingga berpengaruh positif terhadap sikap pengguna akan suatu sistem atau teknologi. Berdasarkan pemaparan di atas, maka hipotesis dari dua variabel tersebut adalah sebagai berikut:

$\mathrm{H}_{1}$ : Perceived ease of use berpengaruh positif terhadap sikap pengguna fintech lending.

$\mathrm{H}_{2}$ : Perceived usefulness berpengaruh positif terhadap sikap pengguna fintech lending.

\subsection{Relative Advantage}

Relative advantage didefinisikan sebagai tingkat inovasi suatu sistem atau teknologi yang dipersepsikan lebih baik dari sebelumnya (Rogers, 1983). Persepsi tersebut muncul ketika 
pengguna mampu mendapatkan hal yang lebih besar atau lebih tinggi daripada ekspektasi yang dimiliki (Krishanan et al., 2015). Relative advantage dapat diperoleh dengan membandingkan inovasi apa yang dimiliki suatu teknologi dengan ekspektasi pengguna atau dengan teknologi lain yang mampu memberikan manfaat yang sama, sehingga relative advantage menjadi faktor penting untuk menentukan apakah suatu teknologi dapat dipakai oleh pengguna ( $\mathrm{Lu}$ et al., 2011). Teknologi dengan tingkat keunggulan yang relatif lebih tinggi dari ekspektasi pengguna akan memberikan dampak positif pada sikap pengguna terhadap suatu teknologi (Shih \& Fang, 2004; Nathania, 2014). Untuk menentukan tingkat relative advantage suatu teknologi, terdapat beberapa indikator yang dapat digunakan, yaitu memiliki fleksibilitas waktu dan tempat untuk diakses yang lebih tinggi, memberikan kenyamanan penggunaan yang lebih besar kepada pengguna, serta memiliki tingkat efisiensi dan efektivitas yang lebih tinggi dibandingkan dengan sistem atau teknologi yang lain (Lu et al., 2011). Lebih lanjut, relative advantage terbukti memberikan dampak positif terhadap sikap pengguna mobile banking (Shih \& Fang, 2004; Krishanan et al., 2015), maka relative advantage juga diduga dapat memberikan dampak positif terhadap sikap pengguna fintech lending.

$\mathrm{H}_{3}$ : Relative advantage berpengaruh positif terhadap sikap pengguna fintech lending.

\subsection{Perceived Risk}

Perceived risk didefinisikan sebagai ketidakpastian yang akan dihadapi oleh seseorang pada saat membuat suatu keputusan (Bertea, 2011). Jika dikaitkan dengan penggunaan suatu sistem atau teknologi, maka perceived risk dapat dijelaskan sebagai risiko keamanan atau risiko privasi mengenai data dan informasi pribadi pengguna dapat diperoleh dan disalahgunakan oleh pihak yang tidak bertanggung jawab (Amaro \& Duarte, 2015; Cham et al., 2016). Terdapat beberapa faktor penting yang dapat menentukan perceived risk yang akan dihadapi oleh pengguna yaitu rasa aman dalam memberikan informasi pribadi yang rahasia ketika menggunakan suatu sistem, kekhawatiran pengguna terhadap kemungkinan pihak lain yang dapat mengakses akun pada saat menggunakan suatu sistem dan rasa aman dalam memberikan informasi yang sensitif ke dalam platform di mana sebuah sistem atau teknologi berjalan (Lu et al., 2011). Jika pengguna menganggap bahwa faktor-faktor tersebut dapat diminimalisir, maka akan menurunkan tingkat perceived risk (Lee, 2009). Perceived risk yang lebih tinggi akan berdampak pada menurunnya sikap pengguna terhadap suatu teknologi dan begitu pula sebaliknya, sehingga perceived risk akan berdampak negatif terhadap sikap pengguna teknologi (Martins et al., 2014). Lebih lanjut, perceived risk terbukti memberikan dampak negatif terhadap pengguna mobile banking (Al-Jabri \& Sohail, 2012; Dineshwar \& Steven, 2013), sehingga perceived risk juga diduga dapat memberikan dampak negatif terhadap sikap pengguna fintech lending.

$\mathrm{H}_{4}$ : Perceived risk berpengaruh negatif terhadap sikap pengguna fintech lending.

\subsection{Perceived Cost}

Perceived cost didefinisikan sebagai persepsi pengguna tentang besarnya biaya yang akan dikeluarkan pada saat menggunakan suatu sistem atau teknologi (Kleijnen et al., 2004). Pada umumnya, biaya menjadi prioritas pengguna ketika menentukan pilihan untuk menggunakan suatu teknologi (Cham, Ng, Lim \& Cheng, 2018), sehingga jika perceived cost tinggi maka akan berakibat pada tertundanya penggunaan teknologi tersebut (Kleijnen et al., 2004). Oleh karena itu, perceived cost memberikan dampak negatif terhadap sikap pengguna (Luarn \& Lin, 2005). Perceived cost memberikan dampak negatif terhadap sikap pengguna pada saat menggunakan 
mobile banking (Wu \& Wang, 2005) dan mobile commerce (Kuo \& Yen, 2009). Meskipun dampak dari perceived cost terhadap fintech lending masih belum dapat dipastikan, namun karena menggunakan teknologi internet dan sistem informasi dalam penggunaannya, maka perceived cost diduga memberikan pengaruh negatif pada sikap pengguna terhadap fintech lending.

$\mathrm{H}_{5}$ : Perceived cost berpengaruh negatif terhadap sikap pengguna fintech lending.

\subsection{Hubungan Sikap terhadap Fintech Lending dengan Minat untuk Menggunakan Fintech Lending}

Sikap dapat didefinisikan sebagai tingkat kecenderungan individu terhadap sesuatu sebagai hasil evaluasi yang telah dilakukan, sedangkan minat dapat didefinisikan sebagai penilaian subjektif individu untuk melakukan sesuatu yang dapat dipengaruhi oleh sikap yang dimiliki (Ajzen, 2002). Jika dikaitkan dengan penggunaan teknologi, maka sikap terhadap teknologi dapat diartikan sebagai tingkat kecenderungan individu terhadap suatu teknologi sebagai hasil evaluasi penggunaan teknologi tersebut, sedangkan minat untuk menggunakan teknologi dapat dimaknai sebagai penilaian subjektif individu untuk menggunakan teknologi yang dapat dipengaruhi oleh sikap terhadap teknologi tersebut (Halilovic \& Cicic, 2013). Sikap pengguna terhadap suatu teknologi dapat ditentukan oleh beberapa faktor, yaitu perasaan nyaman dalam menggunakan teknologi untuk memenuhi tujuannya, pandangan pengguna terhadap manfaat penggunaan teknologi dan pandangan pengguna terhadap tujuan utama dibuatnya suatu teknologi, sedangkan minat pengguna dapat ditentukan oleh faktor keinginan pengguna untuk menggunakan teknologi tersebut (Halilovic \& Cicic, 2013).

Berdasarkan model TAM, sikap pengguna terhadap suatu teknologi memiliki hubungan yang positif dengan minat pengguna untuk menggunakan teknologi tersebut (Davis et al., 1989). Hubungan positif tersebut dapat timbul karena ketika pengguna memiliki pengalaman yang baik dalam menggunakan suatu teknologi, maka akan meningkatkan minatnya untuk menggunakan teknologi tersebut (Venkatesh \& Davis, 2000). Sikap pengguna terhadap suatu teknologi terbukti secara positif meningkatkan minat pengguna untuk menggunakan produk dan layanan fintech (Chuang et al., 2016), internet banking (Lee, 2009) dan mobile banking (Lee, 2016), sehingga dapat diduga bahwa sikap positif pengguna terhadap fintech lending juga akan meningkatkan minat pengguna untuk menggunakan fintech lending.

$\mathrm{H}_{6}$ : Sikap pengguna terhadap fintech lending berpengaruh positif terhadap minat untuk menggunakan fintech lending.

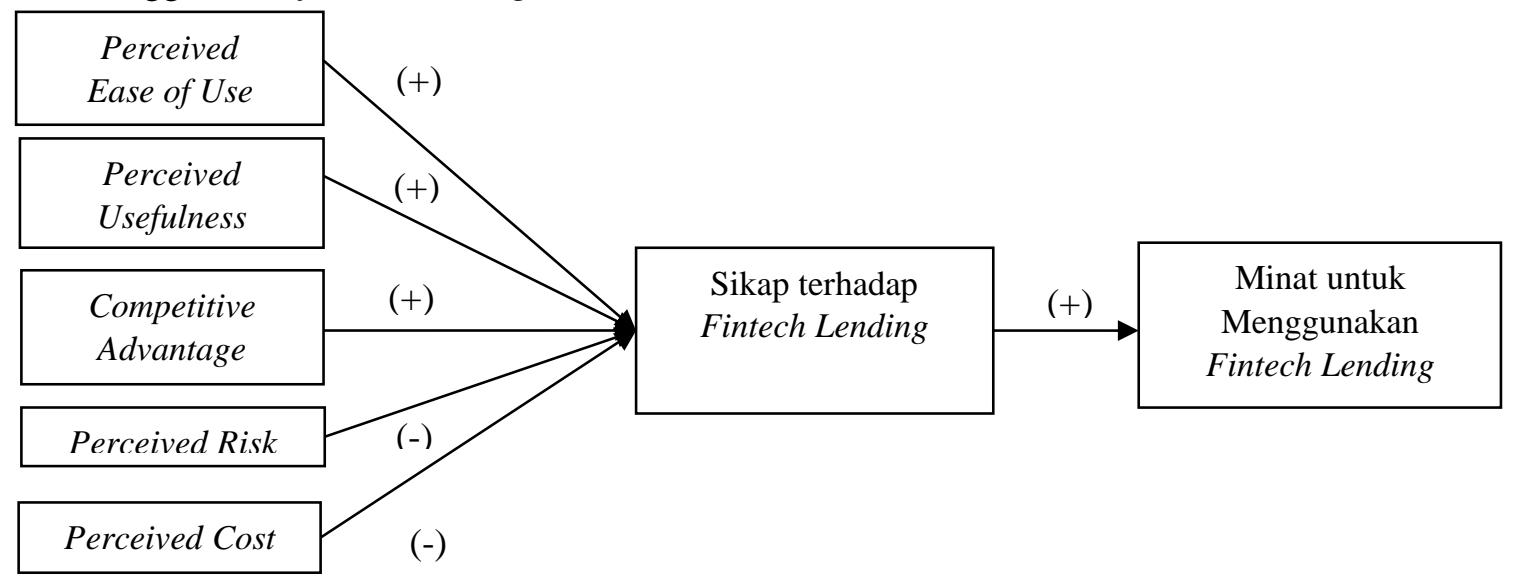

Gambar 1. Kerangka Penelitian 


\section{METODE PENELITIAN}

Penelitian ini bertujuan untuk mengadopsi kerangka kerja Huei et al. (2018) yang menggunakan beberapa variabel tambahan untuk mengembangkan model dasar TAM karena selain belum ada penelitian yang menerapkan kerangka kerja tersebut di Indonesia serta belum ada penelitian yang menggunakan kerangka kerja tersebut untuk diterapkan pada fintech lending. Populasi penelitian ini adalah seluruh mahasiswa aktif di Fakultas Ekonomika dan Bisnis Universitas Kristen Satya Wacana (FEB UKSW) Salatiga dengan jumlah 2.964 mahasiswa (Kemenristekdikti, 2019). Kemudian, dengan menggunakan tabel Krejcie \& Morgan (1970), maka jumlah sampel yang dibutuhkan untuk penelitian ini adalah sebanyak 341 sampel dengan proporsi yang dapat dilihat pada Tabel 1 .

Tabel 1. Rincian Sampel Penelitian

\begin{tabular}{llrr}
\hline Strata & Program Studi & Mahasiswa 2019/ 2020 & Jumlah Sampel \\
\hline Strata 1 & Akuntansi & 1.090 & 125 \\
& Ekonomi Pembangunan & 274 & 32 \\
& Manajemen & 1.398 & 161 \\
Strata 2 & Akuntansi & 63 & 7 \\
& Manajemen & 81 & 9 \\
Strata 3 & Manajemen & 58 & 7 \\
\hline
\end{tabular}

Teknik stratified random sampling digunakan dengan bantuan perangkat lunak daring onlinenumbertools.com untuk menentukan secara acak Nomor Induk Mahasiswa (NIM) yang akan dijadikan sampel dan pengumpulan data menggunakan metode survey yang dilakukan dengan cara memberikan kuesioner secara daring melalui pengiriman surat elektronik berisi tautan Google Forms kepada calon responden. Rincian pengukuran untuk masing-masing variabel dapat dilihat pada Tabel 2 berikut ini.

Tabel 2. Pengukuran Variabel

\begin{tabular}{|c|c|}
\hline Variabel & Indikator \\
\hline $\begin{array}{l}\text { Variabel Dependen } \\
\text { Intention Behavior } \\
\text { to Use Fintech Lending (BHV) }\end{array}$ & $\begin{array}{l}1=\text { sangat tidak setuju } ; 2=\text { tidak setuju } ; 3=\text { netral } ; 4=\text { setuju } ; \\
5=\text { sangat setuju }\end{array}$ \\
\hline $\begin{array}{l}\text { Variabel Independen } \\
\text { Perceived Ease of Use (PEoU) }\end{array}$ & $\begin{array}{l}1=\text { sangat tidak setuju } ; 2=\text { tidak setuju } ; 3=\text { netral } ; 4=\text { setuju } ; \\
5=\text { sangat setuju }\end{array}$ \\
\hline Perceived Usefulness (PU) & $\begin{array}{l}1=\text { sangat tidak setuju } ; 2=\text { tidak setuju } ; 3=\text { netral } ; 4=\text { setuju } ; \\
5=\text { sangat setuju }\end{array}$ \\
\hline Relatife Advantage (RA) & $\begin{array}{l}1=\text { sangat tidak setuju } ; 2=\text { tidak setuju } ; 3=\text { netral } ; 4=\text { setuju } ; \\
5=\text { sangat setuju }\end{array}$ \\
\hline Perceived Risk (PR) & $\begin{array}{l}1=\text { sangat tidak setuju } ; 2=\text { tidak setuju } ; 3=\text { netral } ; 4=\text { setuju } ; \\
5=\text { sangat setuju }\end{array}$ \\
\hline Perceived Cost (PC) & $\begin{array}{l}1=\text { sangat tidak setuju } ; 2=\text { tidak setuju } ; 3=\text { netral } ; 4=\text { setuju } ; \\
5=\text { sangat setuju }\end{array}$ \\
\hline Attitude (ATT) & $\begin{array}{l}1=\text { sangat tidak setuju } ; 2=\text { tidak setuju } ; 3=\text { netral } ; 4=\text { setuju } ; \\
5=\text { sangat setuju }\end{array}$ \\
\hline
\end{tabular}

Bagian pertama kuesioner akan meminta responden untuk memberikan informasi dasar yang opsional yaitu nama lengkap dan Nomor Induk Mahasiswa (NIM) dan informasi dasar yang wajib diberikan seperti tahun masuk kuliah di UKSW, jenis kelamin, umur responden, daerah asal 
dan pekerjaan orang tua. Setelah itu pada bagian kedua responden akan diminta memberikan skor pada setiap item kuesioner untuk mengukur perceived ease of use, perceived usefulness, keunggulan relatif, perceived risk dan perceived cost. Perceived ease of use (PeoU) akan diukur dengan lima item indikator yang diadaptasi dari Davis et al. (1989) dan Chuang et al. (2016), yaitu i) kemudahan mendapatkan aplikasi fintech lending, ii) kemudahan mempelajari cara penggunaan aplikasi fintech lending, iii) kemudahan menguasai penggunaan aplikasi fintech lending dalam waktu yang singkat, iv) kemudahan penggunaan aplikasi fintech lending dan v) kemudahan untuk memperoleh pinjaman melalui aplikasi fintech lending. Perceived usefulness (PU) akan diukur dengan lima item indikator, yang diadaptasi dari Davis et al. (1989) dan Chuang et al. (2016), yaitu i) fleksibilitas penggunaan aplikasi fintech lending untuk diakses dan digunakan kapan saja dan di mana saja, ii) kemampuan aplikasi fintech lending mampu memberikan informasi yang saya butuhkan, iii) kenyamanan pengajuan pinjaman dengan menggunakan aplikasi fintech lending, iv) kecepatan memperoleh pinjaman melalui penggunaan aplikasi fintech lending, v) peluang memperoleh pinjaman melalui penggunaan aplikasi fintech lending.

Keunggulan relatif (RA) akan diukur dengan empat item indikator yang diadaptasi dari Lu et al. (2011) yaitu i) keunggulan aplikasi fintech lending dibanding lembaga keuangan konvensional, ii) kenyamanan mengajukan pinjaman melalui aplikasi fintech lending dibandingkan dengan lembaga keuangan konvensional, iii) efisiensi waktu pengajuan pinjaman melalui aplikasi fintech lending dan iv) penggunaan fintech lending untuk memperoleh pinjaman lebih efektif dibandingkan dengan lembaga keuangan konvensional. Perceived risk (PR) akan diukur dengan tiga item indikator yaitu i) rasa aman untuk memberikan informasi pribadi pada saat menggunakan fintech lending, ii) kekhawatiran pada saat menggunakan fintech lending karena ada risiko bahwa pihak lain dapat mengakses akun yang dibuat dan iii) rasa aman ketika memberikan informasi sensitif pada saat menggunakan fintech lending (Lu et al., 2011). Perceived cost (PC) akan diukur dengan dua item indikator yang diadaptasi dari Luarn \& Lin (2005) yaitu i) persepsi bahwa penggunaan fintech lending akan membutuhkan biaya yang besar dan ii) persepsi bahwa penggunaan fintech lending akan membutuhkan biaya tambahan lain yang cukup besar. Lebih lanjut, penelitian ini akan menggunakan tiga item indikator yang akan digunakan untuk mengukur sikap (ATT) pengguna terhadap fintech lending ((i) kenyamanan untuk mencari informasi menggunakan fintech lending kapan saja dan di mana saja, ii) kemenarikan aplikasi fintech lending untuk mendapat pinjaman dan iii) preferensi penggunaan fintech lending untuk memperoleh pinjaman) dan satu item untuk mengukur minat (BHV) untuk menggunakan fintech lending (minat menggunakan fintech lending untuk mengajukan pinjaman) (Davis et al., 1989) untuk kemudian dilakukan analisis atas hasil kuesioner tersebut. Penelitian ini akan menggunakan perangkat lunak IBM SPSS 25 dalam melakukan serangkaian pengujian data. Data penelitian akan digunakan terlebih dahulu untuk melakukan pengujian validitas dan reliabilitas. Data penelitian akan dikatakan valid apabila nilai r-hitung masing-masing item kuesioner lebih tinggi daripada nilai $r$ tabel dan nilai signifikansinya lebih rendah dari 0,05 dan data penelitian akan dikatakan reliabel apabila nilai Cronbach's Alpha masing-masing variabel lebih tinggi dari 0,600. Selain itu, akan dilakukan uji t-independen untuk menilai pengaruh yang diberikan oleh masing-masing variabel independen, apabila nilai signifikansinya lebih rendah atau sama dengan 0,05 maka dapat dikatakan hipotesis diterima dan begitu pula sebaliknya, apabila nilai signifikansi lebih tinggi dari 0,05 maka hipotesis ditolak. Selain itu juga akan dilakukan uji jalur (path analysis) untuk menilai peran mediasi yang diberikan oleh variabel mediasi dalam hubungan antara variabel independen dengan variabel dependen. 


\section{HASIL DAN PEMBAHASAN}

Berdasarkan pengumpulan data yang dilakukan melalui penyebaran kuesioner secara daring kepada seluruh mahasiswa aktif FEB UKSW, terdapat 633 kuesioner yang telah terisi secara lengkap. Jumlah responden di tiap strata telah memenuhi jumlah minimal yang telah ditentukan sehingga telah sesuai dengan tabel Krejcie \& Morgan (1970). Secara lebih rinci, responden penelitian ini dapat dilihat pada Tabel 3 berikut.

Tabel 3. Deskripsi Responden

\begin{tabular}{clrr}
\hline & Karakteristik Responden & Jumlah & Prosentase \\
\hline & S1 Manajemen & 294 & $46,45 \%$ \\
& S1 Akuntansi & 265 & $41,86 \%$ \\
& S1 Ilmu Ekonomi & 46 & $7,27 \%$ \\
Program Studi & S2 Manajemen & 11 & $1,74 \%$ \\
& S2 Akuntansi & 10 & $1,58 \%$ \\
& S3 Manajemen & $7,11 \%$ \\
\hline \multirow{5}{*}{ Tahun Masuk } & $2013-2016$ & 85 & $13,43 \%$ \\
(Angkatan) & 2017 & 89 & $14,06 \%$ \\
& 2018 & 128 & $20,22 \%$ \\
& 2019 & 110 & $17,38 \%$ \\
& 2020 & 221 & $34,91 \%$ \\
\hline \multirow{2}{*}{ Jenis Kelamin } & Laki-laki & 187 & $29,54 \%$ \\
& Perempuan & 446 & $70,46 \%$ \\
\hline \multirow{5}{*}{ Kelompok Umur } & $<23$ tahun & 561 & $88,63 \%$ \\
& $23-28$ tahun & 61 & $9,64 \%$ \\
& $29-35$ tahun & 8 & $1,26 \%$ \\
& $>35$ tahun & 3 & $0,47 \%$ \\
\hline & Sumatera & 26 & $4,11 \%$ \\
& Jawa & 502 & $79,30 \%$ \\
& Kalimantan & 29 & $4,58 \%$ \\
& Sulawesi & 39 & $6,16 \%$ \\
& Bali & 3 & $0,47 \%$ \\
& Nusa Tenggara & 9 & $1,42 \%$ \\
& Maluku & 12 & $1,90 \%$ \\
& Papua & 13 & $2,05 \%$ \\
\hline \multirow{5}{*}{ Pulau Daerah Asal } & & &
\end{tabular}

Tabel 4. Statistik Deskriptif

\begin{tabular}{|c|c|c|c|c|}
\hline Variabel & Mean & Std. Dev. & Min & Max \\
\hline Perceived Ease of Use & 3,831 & 0,845 & 1 & 5 \\
\hline Perceived Usefulness & 3,610 & 0,899 & 1 & 5 \\
\hline Relative Advantage & 3,604 & 0,867 & 1 & 5 \\
\hline Perceived Risk & 3,710 & 1,007 & 1 & 5 \\
\hline Perceived Cost & 2,927 & 0,887 & 1 & 5 \\
\hline Attitude & 3,597 & 0,850 & 1 & 5 \\
\hline Intention Behavior & 3,008 & 0,900 & 1 & 5 \\
\hline
\end{tabular}

Berdasarkan data yang telah diperoleh, semua variabel memiliki nilai terendah 1 dan nilai tertinggi 5. Rata-rata variabel yang digunakan dalam penelitian ini berkisar di angka 2,927 sampai 3,831 sedangkan nilai standar deviasi berada di rentang 0,845 sampai 1,007 (Tabel 4). Kemudian sebelum melakukan uji regresi berganda dan uji jalur (path analysis), pengujian validitas dan reliabilitas perlu dilakukan sebelum setiap item kuesioner dapat digunakan untuk melakukan pengujian pengaruh dan pengujian jalur (path analysis). Semua item yang digunakan dalam penelitian ini memiliki nilai r-hitung yang lebih tinggi dari r-tabel, sehingga dapat dinyatakan valid dan dapat digunakan untuk melakukan pengujian berikutnya. Semua variabel penelitian ini juga memiliki nilai Cronbach's Alpha yang lebih tinggi dari 0,600 sehingga dapat digunakan untuk melakukan pengujian selanjutnya pada Tabel 5 dan Tabel 6 . 
Tabel 5. Hasil Uji Validitas

\begin{tabular}{lcccc}
\hline Variabel & r-Hitung & r-Tabel & Sig. & Hasil \\
\hline PEoU_1 & 0,530 & 0,078 & 0,000 & Valid \\
PeoU_2 & 0,500 & 0,078 & 0,000 & Valid \\
PeoU_3 & 0,486 & 0,078 & 0,000 & Valid \\
PeoU_4 & 0,590 & 0,078 & 0,000 & Valid \\
PeoU_5 & 0,582 & 0,078 & 0,000 & Valid \\
PU_1 & 0,521 & 0,078 & 0,000 & Valid \\
PU_1 & 0,558 & 0,078 & 0,000 & Valid \\
PU_1 & 0,537 & 0,078 & 0,000 & Valid \\
PU_1 & 0,650 & 0,078 & 0,000 & Valid \\
PU_1 & 0,640 & 0,078 & 0,000 & Valid \\
RA_1 & 0,567 & 0,078 & 0,000 & Valid \\
RA_1 & 0,630 & 0,078 & 0,000 & Valid \\
RA_1 & 0,625 & 0,078 & 0,000 & Valid \\
RA_1 & 0,642 & 0,078 & 0,000 & Valid \\
PR_1 & 0,275 & 0,078 & 0,000 & Valid \\
PR_1 & 0,267 & 0,078 & 0,000 & Valid \\
PR_1 & 0,296 & 0,078 & 0,000 & Valid \\
PC_1 & 0,231 & 0,078 & 0,000 & Valid \\
PC_2 & 0,192 & 0,078 & 0,000 & Valid \\
ATT_1 & 0,592 & 0,078 & 0,000 & Valid \\
ATT_1 & 0,587 & 0,078 & 0,000 & Valid \\
ATT_1 & 0,599 & 0,078 & 0,000 & Valid \\
BHV_1 & 0,445 & 0,078 & 0,000 & Valid \\
\hline
\end{tabular}

Tabel 6. Hasil Uji Reliabilitas

\begin{tabular}{lccc}
\hline Variabel & Cronbach's Alpha & Standard & Hasil \\
\hline Perceived Ease of Use & 0,792 & 0,600 & Reliabel \\
Perceived Usefulness & 0,748 & 0,600 & Reliabel \\
Relative Advantage & 0,800 & 0,600 & Reliabel \\
Perceived Risk & 0,860 & 0,600 & Reliabel \\
Perceived Cost & 0,845 & 0,600 & Reliabel \\
Attitude & 0,716 & 0,600 & Reliabel \\
\hline
\end{tabular}

Hasil pengujian parsial untuk masing-masing hipotesis dapat dilihat pada Tabel 7 di bawah ini. PEOU memiliki pengaruh yang tidak signifikan terhadap attitude $(\beta=0,026, \mathrm{p}>0,01)$, sedangkan perceived usefulness dan relative advantage secara parsial memberikan pengaruh positif yang signifikan terhadap attitude $(\beta=0,410, \mathrm{p}<0,01 ; \beta=0,372, \mathrm{p}<0,01)$. Lebih lanjut, perceived risk tidak memberikan pengaruh terhadap attitude $(\beta=-0,022, \mathrm{p}>0,01)$ sedangkan perceived cost memberikan pengaruh negatif yang signifikan terhadap attitude $(\beta=-0,059$, $\mathrm{p}<0,01)$ dan attitude memberikan pengaruh positif yang signifikan terhadap intention behavior $(\beta=0,433, p<0,01)$. Dengan demikian, hasil pengujian pengaruh parsial tersebut dapat dikatakan bahwa hipotesis yang diterima adalah $\mathrm{H}_{2}, \mathrm{H}_{3}, \mathrm{H}_{5}$ dan $\mathrm{H}_{6}$ sedangkan $\mathrm{H}_{1}$ dan $\mathrm{H}_{4}$ ditolak.

Tabel 7. Pengujian Hipotesis

\begin{tabular}{lcccl}
\hline \multicolumn{1}{c}{ Variabel Independen } & Variabel Dependen & Beta Std. & p-value / Sig. & Hasil \\
\hline Perceived Ease of Use & Attitude & 0,026 & 0,463 & Ditolak \\
Perceived Usefulness & Attitude & 0,410 & 0,000 & Diterima \\
Relative Advantage & Attitude & 0,372 & 0,000 & Diterima \\
Perceived Risk & Attitude & $-0,022$ & 0,446 & Ditolak \\
Perceived Cost & Attitude & $-0,059$ & 0,045 & Diterima \\
Attitude & Intention & 0,433 & 0,000 & Diterima \\
\hline
\end{tabular}


Selain melakukan pengujian pengaruh langsung yang diberikan masing-masing variabel, perlu dilakukan analisa dampak tidak langsung sehingga dapat dilihat lebih jauh variabel mana yang memiliki kemampuan untuk memberikan peran mediasi. Metode Variance Accounted For (VAF) merupakan metode yang tepat untuk digunakan dalam menghitung dampak tidak langsung dan jumlah dampak yang dapat dibagi ke dalam beberapa kategori sebagai berikut: i) mediasi penuh, apabila nilai VAF lebih besar dari $80 \%$, ii) mediasi parsial, apabila nilai VAF berada di rentang 20\% sampai $80 \%$ dan iii) tidak ada mediasi, apabila nilai VAF kurang dari $20 \%$ (Hair, Black, Babin \& Anderson, 2006). Tabel 8 di bawah ini menunjukkan bahwa attitude mampu memberikan mediasi parsial pada pengaruh yang diberikan oleh perceived usefulness dan relative advantage terhadap intention behavior, namun tidak mampu memberikan mediasi pada pengaruh yang diberikan oleh perceived ease of use, perceived risk dan perceived cost terhadap intention behavior.

Tabel 8. Hasil Perhitungan Peran Mediasi Metode VAF

\begin{tabular}{|c|c|c|c|c|}
\hline Dampak Langsung & Dampak Tidak Langsung & $\begin{array}{c}\text { Total } \\
\text { Dampak }\end{array}$ & VAF & Hasil \\
\hline $\begin{array}{c}\text { PEOU } \rightarrow \text { Intention } \\
-0,225\end{array}$ & $\begin{array}{c}\text { (PEOU -> Att) x (Att -> Int }) \\
0,026 \times 0,433 \\
0,011\end{array}$ & $-0,214$ & $-0,053$ & $\begin{array}{l}\text { Tidak Ada } \\
\text { Mediasi }\end{array}$ \\
\hline $\begin{array}{c}\text { PU } \rightarrow>\text { Intention } \\
0,236\end{array}$ & $\begin{array}{c}(\mathrm{PU}->\mathrm{Att}) \times(\mathrm{Att}->\mathrm{Int}) \\
0,410 \times 0,433 \\
0,178\end{array}$ & 0,414 & 0,429 & $\begin{array}{l}\text { Mediasi } \\
\text { Parsial }\end{array}$ \\
\hline $\begin{array}{c}\mathrm{RA} \rightarrow>\text { Intention } \\
0,082\end{array}$ & $\begin{array}{c}(\mathrm{RA}->\mathrm{Att}) \times(\mathrm{Att}->\mathrm{Int}) \\
0,372 \times 0,433 \\
0,161\end{array}$ & 0,243 & 0,663 & $\begin{array}{l}\text { Mediasi } \\
\text { Parsial }\end{array}$ \\
\hline $\begin{array}{c}\mathrm{PR}->\text { Intention } \\
\quad-0,205\end{array}$ & $\begin{array}{c}(\mathrm{PR}->\mathrm{Att}) \times(\mathrm{Att}->\mathrm{Int}) \\
-0,022 \times 0,433 \\
-0,010\end{array}$ & $-0,215$ & 0,044 & $\begin{array}{l}\text { Tidak Ada } \\
\text { Mediasi }\end{array}$ \\
\hline $\begin{array}{c}\mathrm{PC}->\text { Intention } \\
0,163\end{array}$ & $\begin{array}{c}\text { (PEOU }->\text { Att }) \times(A t t->\text { Int }) \\
-0,059 \times 0,433 \\
-0,026\end{array}$ & 0,137 & $-0,186$ & $\begin{array}{c}\text { Tidak Ada } \\
\text { Mediasi }\end{array}$ \\
\hline
\end{tabular}

Penelitian ini bertujuan untuk menguji faktor-faktor yang berpengaruh terhadap minat untuk menggunakan fintech lending. Berdasarkan pengujian yang telah dilakukan dapat disimpulkan bahwa dari enam hipotesis, terdapat empat hipotesis yang diterima sedangkan dua sisanya ditolak. Perceived usefulness memberikan pengaruh positif yang signifikan terhadap attitude sehingga dapat dimaknai bahwa ketika pengguna merasa telah memperoleh dampak langsung berupa manfaat dari penggunaan fintech lending maka pengguna akan memberikan sikap yang positif terhadap fintech lending. Relative advantage juga memberikan pengaruh positif yang signifikan terhadap attitude sehingga dapat dimaknai bahwa ketika fintech lending mampu memiliki suatu keunggulan berupa fitur atau inovasi yang mampu melebihi ekspektasi pengguna maka pengguna akan memberikan sikap yang positif terhadap fintech lending sama seperti sikap positif terhadap fintech mobile payment. Hal tersebut mendukung hasil penelitian sebelumnya yang menyatakan bahwa sikap seseorang terhadap suatu teknologi dipengaruhi oleh perceived usefulness (Al-Fahim et al., 2016; Elkaseh, Wong \& Fung, 2016; Morgan-Thomas \& Veloutsou, 2013) dan relative advantage (Krishanan et al., 2015; Lu et al., 2011; Nathania, 2014).

Perceived cost memberikan pengaruh negatif yang signifikan terhadap attitude sehingga dapat dimaknai bahwa pengguna fintech lending menyadari akan ada biaya yang timbul untuk dapat menggunakan suatu teknologi. Oleh karena itu, persepsi mengenai biaya yang semakin tinggi akan berdampak negatif terhadap sikap pengguna fintech lending yang akan digunakan. Hal 
tersebut mendukung hasil penelitian sebelumnya yang menyatakan bahwa biaya menjadi prioritas pengguna (Cham et al., 2018), sehingga perceived cost yang semakin tinggi berdampak negatif pada sikap pengguna dan mengakibatkan tertundanya penggunaan teknologi tersebut (Kuo \& Yen, 2009; Luarn \& Lin, 2005; Wu \& Wang, 2005). Lebih lanjut, sikap pengguna terhadap fintech lending memberikan pengaruh positif yang signifikan terhadap minat untuk menggunakan fintech lending. Hal tersebut dapat dimaknai bahwa semakin baik hasil evaluasi pengguna atas penggunaan suatu teknologi berdasarkan pengalamannya maka akan meningkatkan minat individu untuk menggunakan teknologi tersebut dalam memenuhi kebutuhannya. Penjelasan di atas mendukung hasil penelitian sebelumnya yang menyatakan bahwa sikap pengguna mampu memberikan dampak positif terhadap minat penggunaan mobile banking dan produk fintech lainnya (Chuang et al., 2016; Lee, 2016).

Perceived ease of use memberikan pengaruh yang positif namun tidak signifikan terhadap attitude yang dapat disebabkan oleh responden dalam penelitian ini merupakan mahasiswa aktif yang didominasi oleh umur kurang dari 23 tahun $(88,63 \%)$ yang belum bekerja, sehingga meskipun responden dominan tersebut dapat dengan mudah mendapatkan aplikasi fintech lending, mereka tidak dapat mengajukan pinjaman karena salah satu syarat utama untuk memperoleh pinjaman adalah memiliki penghasilan. Hal ini akan berperan pula pada perceived risk yang memberikan pengaruh yang negatif namun tidak signifikan terhadap attitude, karena belum dapat menggunakan aplikasi fintech lending secara maksimal khususnya dalam mengajukan pinjaman, maka responden dominan tersebut belum memasukkan data dan informasi yang sifatnya pribadi dan sensitif sehingga tidak ada kekhawatiran mengenai risiko bahwa pihak lain dapat mengakses akun yang dibuat. Hal ini bertentangan dengan Davis et al. (1989) dan Chuang et al. (2016) di mana agar dapat memberikan penilaian mengenai usaha yang diperlukan dalam mempelajari suatu teknologi, pengguna harus menggunakan teknologi tersebut dalam rentang waktu tertentu dalam mencapai suatu tujuan tertentu. Lebih lanjut, hasil tersebut juga berbeda dengan penelitian sebelumnya oleh Yuniarti \& Ekowati (2019) yang sampel penelitiannya adalah pengguna layanan fintech lending.

Lebih lanjut, penelitian ini juga menunjukkan bahwa sikap mampu memberikan mediasi parsial terhadap dampak yang diberikan oleh perceived usefulness dan relative advantage pada minat penggunaan fintech lending. Namun, di sisi lain sikap tidak mampu memberikan mediasi terhadap dampak yang diberikan oleh perceived ease of use, perceived risk dan perceived cost pada minat sehingga total dampak yang diberikan masing-masing menjadi beragam. Total dampak yang diberikan oleh perceived usefulness dan relative advantage lebih tinggi dibandingkan dengan dampak langsung yang diberikan terhadap minat penggunaan fintech lending. Namun demikian, berbeda dengan total dampak yang diberikan oleh perceived ease of use, perceived risk dan perceived cost meskipun dampak tidak langsung yang dimiliki masing-masing lebih besar dibandingkan dengan dampak langsung yang diberikan, sehingga total dampak yang diberikan tidak menghasilkan nilai VAF yang cukup untuk memberikan peran mediasi. Hal tersebut dapat dimaknai bahwa meskipun secara umum sikap mampu memberikan peran mediasi, dampak tidak langsung yang diberikan tidak selalu lebih besar dibandingkan dengan nilai dampak langsung, sehingga sikap tidak selalu mampu menjadi variabel mediasi khususnya dalam penelitian ini.

\section{SIMPULAN DAN REKOMENDASI}

Pengujian yang dilakukan terhadap faktor-faktor yang mempengaruhi minat untuk menggunakan fintech lending menunjukkan bahwa perceived usefulness, relative advantage dan 
perceived cost mempengaruhi sikap pengguna fintech lending, sedangkan perceived ease of use dan perceived risk tidak mempengaruhi sikap terhadap fintech lending. Selain itu, sikap terhadap fintech lending mempengaruhi minat untuk menggunakan fintech lending. Hasil lain yang diperoleh dari penelitian ini adalah meskipun sikap terhadap fintech lending mampu memberikan dampak tidak langsung yang relatif lebih tinggi dari dampak langsung yang diberikan oleh masingmasing variabel, sikap terhadap fintech lending hanya mampu menjadi mediator parsial bagi variabel perceived usefulness dan relative advantage. Dapat disimpulkan bahwa sikap terhadap fintech lending lebih dipengaruhi oleh adanya manfaat yang diperoleh, keunggulan yang melebihi ekspektasi pengguna dan biaya yang relatif rendah, sedangkan minat untuk menggunakan fintech lending dipengaruhi oleh sikap terhadap fintech lending itu sendiri yang sekaligus menjadi pemediasi variabel-variabel independen.

Hasil penelitian ini juga mampu membuktikan bahwa sama seperti model TAM yang menyatakan bahwa perceived ease of use memberikan pengaruh yang tidak signifikan pada sikap terhadap fintech lending. Hal ini mungkin dapat diakibatkan oleh masih tingginya waktu untuk mempelajari penggunaan fintech lending dalam mencapai tujuan tertentu, sehingga langkah yang perlu dilakukan oleh perusahaan penyedia jasa fintech lending adalah mengedukasi calon pengguna bahwa penggunaan fintech lending untuk tujuan tertentu relatif lebih mudah, di samping mengedukasi bahwa penyedia jasa fintech lending mampu untuk melindungi kerahasiaan data dan informasi pengguna. Selain itu, penelitian ini juga bermanfaat untuk perkembangan model TAM melalui hasil yang menyatakan bahwa relative advantage dan perceived cost memberikan pengaruh yang sama terhadap fintech lending sama seperti dengan fintech lain (mobile banking, mobile commerce atau fintech payment) yang menggunakan teknologi internet. Keterbatasan penelitian ini adalah responden yang merupakan mahasiswa yang mungkin belum pernah menggunakan aplikasi fintech lending untuk mengajukan pinjaman, sehingga perlu dilakukan penelitian lebih lanjut dengan menggunakan metode pengambilan sampel berupa snowball sampling untuk memperoleh responden yang sudah memiliki pekerjaan dan sudah pernah menggunakan aplikasi fintech lending untuk mengajukan pinjaman.

\section{DAFTAR PUSTAKA}

Agarwal, S., \& Chua, Y. H. (2020). FinTech and household finance: a review of the empirical literature. China Finance Review International, 10(4), 361-376.

Ajzen, I. (2002). Perceived behavioral control, self-efficacy, locus of control, and the theory of planned behavior. Journal of Applied Social Psychology, 32(4), 665-683.

Al-Fahim, N. H., Jusoh, W. J. W., \& Abideen, A. (2016). Factors Affecting the Adoption of Internet Banking Services Among Small and Medium Enterprises in Yemen. Global Advanced Research Journal of Management and Business Studies, 3(9). 432-330.

Al-Jabri, I. M. \& Sohail, M. S. (2012). Mobile Banking Adoption: Application of Diffusion of Innovation Theory. Journal of Electronic Commerce Research, 13(4), 379-391.

Amalia, F. (2016). Book Review: The Fintech Book: The Financial Technology Handbook for Invenstors, Entrepreneurs and Visionaires. Journal of Indonesian Economy and Business, $31(3), 345-348$.

Amaro, S., \& Duarte, P. (2015). An integrative model of consumers' intentions to purchase travel online. Tourism Management, 46, 64-79. 
Bertea, P. E. (2011). Perceived Risk and Online Shopping Behaviour - A Marketing Perspective. SSRN Electronic Journal.

Bofondi, M., \& Gobbi, G. (2017). The Big Promise of Fintech. European Economy (Bank, Regulation and the Real Sector): Fintech and Banking. Friends or Foes?, 2, 107-119.

Cham, T. H., Lim, Y. M., Cheng, B. L., \& Lee, T. H. (2016). An Empirical Study on the Determinants of Knowledge Management Systems Success - Evidence from the Banking Industry of Malaysia. VINE Journal of Information and Knowledge Management Systems, 46(1), 2-20.

Cham, T. H., Ng, C. K. Y., Lim, Y. M., \& Cheng, B. L. (2018). Factors Influencing Clothing Interest and Purchase Intention: A Study of Generation Y Consumers in Malaysia. The International Review of Retail, Distribution and Consumer Research, 28(2), 174-189.

Chuang, L.-M., Liu, C.-C., \& Kao, H.-K. (2016). The Adoption of Fintech Service: TAM perspective. International Journal of Management and Administrative Sciences (IJMAS), $3(07), 1-15$.

Chisti, S., \& Barberis, J. (2016). The FINTECH Book: The Financial Technology Handbook for Investors, Entrepreneurs and Visionaries. West Sussex: Wiley.

Davis, D. F. (1986). A Technology Acceptance Model for Empirically Testing New End-User Information Systems: Theory and Results (Doctoral dissertation). Massachusets Institute of Technology, Cambridge, Massachusetts, United States.

Daily Social Research. (2019). Type of Fintech. Moving Towards A New Era In Indonesia's Financial Industry | Fintech Report 2019.

Darmansyah, Fianto, B.A., Hendratmi, A. \& Aziz, P.F. (2020). Factors determining behavioral intentions to use Islamic financial technology: Three competing models. Journal of Islamic Marketing, August 2020.

Davis, F. D., Bagozzi, R. P., \& Warshaw, P. R. (1989). User Acceptance of Computer Technology: A Comparison of Two Theoretical Models. Management Science, 35(8), 982-1003.

Dineshwar, R., \& Steven, M. (2013). An Investigation on Mobile Banking Adoption and Usage: A Case Study of Mauritius. Proceedings of $3^{\text {rd }}$ Asia-Pacific Business Research Conference 25-26 February 2013. ISBN: 978-1-922069-19-1. Kuala Lumpur, Malaysia

Elkaseh, A. M., Wong, K. W., \& Fung, C. C. (2016). Perceived Ease of Use and Perceived Usefulness of Social Media for e-Learning in Libyan Higher Education: A Structural Equation Modeling Analysis. International Journal of Information and Education Technology, 6(3), 192-199.

Financial Stability Board. (2017). Financial Stability Implications from Fintech: Supervisory and Regulatory Issues that Merit Authorities' Attention. Financial Stability Board, 27 June 2017, page 55 .

Fishbein, M., \& Ajzen, I. (1975). Belief, Attitude, Attention and Behavior: An Introduction to Theory and Research. Philippines: Addison-Wesley Publishing Company.

Google, Temasek, \& Bain. (2019). e-Conomy SEA 2019. Swipe Up and to The Right: Southeast Asia's $\$ 100 \quad$ Billion Internet Economy. Diunduh dari https://www.thinkwithgoogle.com/intl/en-apac/consumer-insights/consumer-trends/economy-sea-2019-swipe-up-and-to-the-right-southeast-asias-100-billion-interneteconomy/

Hair, J. F., Black, W. C., Babin, B. J., \& Anderson, R. E. (2006). Multivariate Data Analysis (6th ed.). Upper Saddle River, New Jersey: Pearson Education. 
Halilovic, S., \& Cicic, M. (2013). Antecedents of information systems user behaviour-extended expectation-confirmation model. Behaviour and Information Technology, 32(4), 359-370.

Huei, C. T., Cheng, L. S., Seong, L. C., Khin, A. A., \& Bin, R. L. L. (2018). Preliminary study on consumer attitude towards fintech products and services in malaysia. International Journal of Engineering and Technology(UAE), 7(2), 166-169.

Kalinić, Z., Liébana-Cabanillas, F. J., Muñoz-Leiva, F., \& Marinković, V. (2019). The moderating impact of gender on the acceptance of peer-to-peer mobile payment systems. International Journal of Bank Marketing, 38(1), 138-158.

Kementerian Riset Teknologi dan Pendidikan Tinggi. (2019). Profil Perguruan Tinggi. Diunduh dari https://rb.gy/2gmpym

Kim, Y., Park, Y.-J., Choi, J., \& Yeon, J. (2015). An Empirical Study on the Adoption of "Fintech" Service: Focused on Mobile Payment Services. Advanced Science and Technology Letters $114,136-140$.

Kleijnen, M., Wetzels, M., \& de Ruyter, K. (2004). Consumer acceptance of wireless finance. Journal of Financial Services Marketing, 8(3), 206-217.

Krejcie, R. V., \& Morgan, D. W. (1970). Dertermining Sample Size for Research Activities. Educational and Psychological Measurement, 30, 607-610.

Krishanan, D., Khin, A., \& Teng, K. (2015). Attitude towards Using Mobile Banking in Malaysia: A Conceptual Framework. British Journal of Economics, Management \& Trade, 7(4), 306-315.

Kuo, Y. F., \& Yen, S. N. (2009). Towards an understanding of the behavioral intention to use 3G mobile value-added services. Computers in Human Behavior, 25(1), 103-110.

Kurniawan, R. (2019). Examination of the Factors Contributing to Financial Technology Adoption in Indonesia using Technology Acceptance Model: Case Study of Peer to Peer Lending Service Platform. Proceedings of 2019 International Conference on Information Management and Technology, ICIMTech 2019, 1, 432-437.

Kurniawan, T. A., Wardani, D. K., \& Widhayati, L. (2019). Pengaruh Keberterimaan Layanan Peer To Peer Lending Kepada Umkm Sebagai Pengguna Dengan Menggunakan Metode Technology Acceptance Model (TAM). Jurnal Sosial Ekonomi Dan Humaniora, 5(2), 151-160.

Lee, M. C. (2009). Factors influencing the adoption of internet banking: An integration of TAM and TPB with perceived risk and perceived benefit. Electronic Commerce Research and Applications, 8(3), 130-141.

Lee, S. (2016). User behavior of mobile enterprise applications. KSII Transactions on Internet and Information Systems, 10(8), 3972-3985.

Lu, Y., Yang, S., Chau, P. Y. K., \& Cao, Y. (2011). Dynamics between the trust transfer process and intention to use mobile payment services: A cross-environment perspective. Information and Management, 48(8), 393-403.

Luarn, P., \& Lin, H. H. (2005). Toward an understanding of the behavioral intention to use mobile banking. Computers in Human Behavior, 21(6), 873-891.

Martins, C., Oliveira, T., \& Popovič, A. (2014). Understanding the internet banking adoption: A unified theory of acceptance and use of technology and perceived risk application. International Journal of Information Management, 34(1), 1-13. 
Morgan-Thomas, A., \& Veloutsou, C. (2013). Beyond technology acceptance: Brand relationships and online brand experience. Journal of Business Research, 66(1), 21-27.

Muk, A., \& Chung, C. (2015). Applying the technology acceptance model in a two-country study of SMS advertising. Journal of Business Research, 68(1), 1-6.

Nathania, I. (2014). Pengaruh Trust, Relative Advantage, Complexity, Compatibility, Image, Result Demonstrability dan Visibility terhadap Minat Menggunakan Website untuk Berbelanja di tokobagus.com (Skripsi yang tidak dipublikasikan). Widya Mandala Catholic University, Surabaya, Indonesia.

OJK. (2020). Perusahaan Fintech Lending Terdaftar/ Berizin. Diunduh dari https://www.ojk.go.id/id/kanal/iknb/financial-technology/Pages/-Penyelenggara-FintechTerdaftar-dan-Berizin-di-OJK-per-14-Agustus-2020.aspx

Pantano, E., \& Di Pietro, L. (2012). Understanding consumer's acceptance of technology-based innovations in retailing. Journal of Technology Management and Innovation, 7(4), 1-19.

Rogers, E. M. (1983). Diffusion Of Innovation. New York: The Free Press.

Rosavina, M., Rahadi, R. A., Kitri, M. L., Nuraeni, S., \& Mayangsari, L. (2019). P2P lending adoption by SMEs in Indonesia. Qualitative Research in Financial Markets, 11(2), 260279.

Santoso, B., \& Erwin, Z. (2020). Analisis Persepsi Pengguna Aplikasi Payment Berbasis Fintech Menggunakan Technology Acceptance Model (TAM). Jurnal Teknologi Informasi Dan Komunikasi, 11(1), 49-54.

Shih, Y. Y., \& Fang, K. (2004). The use of a decomposed theory of planned behavior to study Internet banking in Taiwan. Internet Research, 14(3), 213-223.

Sijabat, Y. P., Hutajulu, D.M., \& Sihombing, P. (2019). Determinasi Technology Acceptance Model Terhadap Niat Penggunaan Fintech Sebagai Alat Pembayaran (Payment). Fintech dan E-Commerce untuk Mendorong Pertumbuhan UMKM dan Industri Kreatif: Prosiding Seminar Nasional Dan Call For Papers Fakultas Ekonomi Universitas Tidar, Magelang, 15 Oktober 2019

Suyanto, \& Kurniawan, T. A. (2019). Faktor yang Mempengaruhi Tingkat Kepercayaan Penggunaan Fintech pada UMKM dengan Menggunakan Teknologi Acceptance Model (TAM). Jurnal Akuntansi Dan Manajemen Akmenika, 16(1), 175-186.

Svendsen, G. B., Johnsen, J. A. K., Almås-Sørensen, L., \& Vittersø, J. (2013). Personality and technology acceptance: The influence of personality factors on the core constructs of the Technology Acceptance Model. Behaviour and Information Technology, 32(4), 323-334.

Tarhini, A., Hassouna, M., Abbasi, M. S., \& Orozco, J. (2015). Towards the acceptance of RSS to support learning: An empirical study to validate the technology acceptance model in Lebanon. Electronic Journal of E-Learning, 13(1), 30-41.

Venkatesh, V., \& Davis, F. D. (2000). Theoretical extension of the Technology Acceptance Model: Four longitudinal field studies. Management Science, 46(2), 186-204.

Vuković, M., Pivac, S., \& Kundid, D. (2019). Technology Acceptance Model for the Internet Banking Acceptance in Split. Business Systems Research, 10(2), 124-140.

Wei, S. (2016). Designing optimal regulation for financial innovation in Capital raising regulatory options for China's peer-to-peer lending sector. Banking and Finance Law Review, 31(3), 539-572. 
Wu, J. H., \& Wang, S. C. (2005). What drives mobile commerce? An empirical evaluation of the revised technology acceptance model. Information and Management, 42(5), 719-729.

Yuniarti, V., \& Ekowati, W. H. (2019). Faktor-Faktor yang Mempengaruhi Minat Penggunaan Financial Technology Peer to Peer Lending. Journal of Chemical Information and Modeling, 53(9), 1689-1699. 